Table 1. Recoveries of Saskatchewan-banded White Pelicans.

\begin{tabular}{lllrrr}
\hline Bander & Lake & Years & Banded & Recov. & \% Recov. \\
\hline J. A. M. Patrick & Quill & $1930-32$ & 985 & 71 & $7.2 \%$ \\
Fred G. Bard & Quill & $1931-37$ & 325 & 34 & $10.5 \%$ \\
\multicolumn{1}{c}{ " } & Last Mountain & 1948 & 41 & 1 & $2.4 \%$ \\
Lyon \& McArthur & Old Wives & 1958 & 591 & 44 & $7.4 \%$ \\
Gresham \& Haak & Redberry & $1936-37$ & 328 & 36 & $11.0 \%$ \\
C. S. Houston & Last Mountain & 1939 & 21 & 3 & $14.3 \%$ \\
\multicolumn{1}{c}{$"$} & Dore & 1954 & 15 & 1 & $6.7 \%$ \\
\multicolumn{1}{c}{ " } & Quill & $1956-58$ & 395 & 20 & $5.7 \%$ \\
& Crane & $1960-61$ & 130 & 13 & $10.0 \%$ \\
& Redberry & $1955-64$ & 1258 & 82 & $6.5 \%$ \\
\hline
\end{tabular}

with previous years. This may indicate an increased reporting of birds found by citizens of Mexico, or wider dispersal of the birds, or both, but recent recoveries now give a complete coverage of the gulf shore from Florida all the way around the eastern coast of Mexico to Yucatan.

\section{LITERATURE CITED}

Behle, W. H. 1958. The bird life of Great Salt Lake. University of Utah Press, Salt Lake City.
Diem, K. L., and D. D. Condon. 1967. Banding studies of water birds on the Molly Islands Yellowstone Lake, Wyoming. Yellowstone Libraary and Museum Assn., Yellowstone National Park.

Houston, C. S. 1967. Saskatehewan bird banders: Judge J. A. M. Patrick (18731943). Blue Jay, $25: 172-174$.

Houston, C. S. 1968. Saskatchewan banders: William I. Lyon and H. E. McArthur. Blue Jay, $26: 185-187$.

Houston, C. S. 1970. Saskatchewan bird banders ; Fred G. Bard. Blue Jay. $28: 150-156$.

Houston C. S. 1971. Recent Saskatchewan banding of the Double-crested Cormorant. Blue Jay, $29: 74-79$.

\title{
WINTER WREN, SPRAGUE'S PIPIT AND OTHER RECORDS AT CHURCHILL
}

By Richard A. Forster, Massachusetts Audubon Society Lincoln, Massachusetts 01773

Summary accounts of Churchill birds by Jehl and Smith have recently been made available (Birds of the Churchill region, Manitoba. Manitoba Museum of Man \& Nature, Spec. Publ. No. 1, Winnipeg, 1970). Since their publication appeared, some significant records obtained by $R$. Pittaway and others were published in the June 1971 Blue Jay (29:60-63).

A few observations made at Churchill in 1971 by members of a Massachusetts Audubon Society tour and myself, including first reports of Winter Wren and Sprague's Pipit, seem worth recording.

Harlequin Duck

Histrionicus histrionicus

A drake was observed at Cape Merry on the evening of June 25, 1971.

This is the second record for the area, a male having been seen from July 11 to July 14,1970 at the same place by Pittaway and I. Newton (Blue Jay, 29:60).

\section{Yellow Rail}

\section{Coturnicops noveboracensis}

Heard calling at Landing Lake on June 24, 1971 and subsequently. This matches the first date of their occurrence recorded by Pittaway in 1970 (Blue Jay, 29:60).

Great Yellowlegs Tringa melanoleuca

Seven were found at the Goose Creek Road on June 23, 1971. The species was considered "accidental in spring" by Jehl and Smith (1970:40). Ring-billed Gull Larus delawarensis

A single bird was seen several times at the Fort Churchill dump from June 21-25, 1971. 
Sighted on three previous occasions, June 14, 1968 (one) (Jehl and Smith, 1970: 51), June 19, 1970 (three) and July 2, 1970 (one) (Blue Jay, 29:62).

\section{Cliff Swallow}

\section{Petrochelidon pyrrhononta}

One was observed flying along the Goose Creek Road on June 23, 1971.

One previous record, a bird sighted on June 11, 1970 by Pittaway and J. Rosenband (Blue Jay 29: 63).

Winter Wren Troglodytes troglodytes

The distinctive song of this species was heard near the beginning of the Goose Creek Road on June 23, 1971, but it was too windy to record its voice.

An accidental visitor. No previous records are known for the Churchill area. The nearest breeding range according to Godfrey (The birds of Canada. Natl. Mus. Can. Bull. 203,
1966) is far to the south in the forested region of southern Manitoba; however, strays have been found as far north as southern Yukon and southern Mackenzie.

\section{Sprague's Pipit Anthus spragueii}

A male in flight song was seen in the tundra area below the Northern Lights Observatory on June 24, 1971. Its flight song was recorded on tape.

An accidental visitor from the southern prairies - not previously reported for the Churchill region.

\section{Northern Shrike Lanius excubitor}

A nest with three young was found at the Rocket Range on June 23, 1971.

Jehl and Smith (1970: 65) considered it a "rare summer resident in varying numbers" though fairly common in scme years.

\section{FIELD OBSERVATIONS OF POSSIBLE TRUMPETER SWANS NEAR SASKATOON \\ by J. B. Gollop, Canadian Wildlife Service, Saskatoon}

On August 29, 1971, I saw a swan on the west side of Goose Lake, about 40 miles southwest of Saskatoon. The bird was studied in full sun for more than 10 minutes until $4: 10$ p.m. with a $25 \times 60$ Ralscope at a distance of 250 300 yards. The swan spent most of the time preening; it looked around for several minutes and walked about 25 feet before swimming slowly away. The bird was in adult plumage and had a solid black bill except for the pink edge of the posterior half of the mandible. Robbins, Bruun and Zim (1966: 38) state that this mark is diagnostic for Trumpeter Swans (Olor buccinator). It is well illustrated in a colour photograph of a Trumpeter in Wetmore $(1966: 143)$. The large proportion and pattern of black on the head was also almost identical to the illustration in Robbins et al. Kortwright (1942:77) and Delacour (1954:82) write that the pink bill edging is found on the Trumpeter but not on the Whistling Swan (Olor columbianus). Banko (1960:66), however, states that he has seen salmon colouring on some
Whistling Swans. "So, for all practical purposes, the salmon color usually present on the dorsal portion of the basal edge of the lower mandible cannot furnish a positive indicator of either species, since overlapping characteristics are commonly observed." (Banko, p. 67). Banko (p. 65) also states "a completely black bill can represent either species ...."

There were two other reports of swans this summer in the Saskatoon area. On or about August 10, Ewen Coxworth and three companions saw two swans together on the South Saskatchewan River about 9 miles south of the city. On August 22, Geoffrey Galloway and several other canoeists saw a swan near Macpherson Island, within a mile of the August 10 observation. From its call, the latter bird was believed to be a Trumpeter Swan.

These birds may well have been swans from the Cypress Hills wandering northward, a late summer movement characteristic of many species of birds. The arctic-nesting Whistling Swan has not been recorded in the 